\title{
Collaborative Leadership in the School Community: School Counselors and Principals Join Forces for Linguistically Diverse Students
}

\author{
Nadire Gülçin YILDIZ ${ }^{1}$ \\ ${ }^{1}$ Istanbul Medipol University, ORCID ID: 0000-0002-5852-9658 \\ Email: ngyildiz@medipol.edu.tr
}

\begin{abstract}
The numbers of diverse students are increasing within the school system, demanding necessary changes in school leadership to meet the needs of students from linguistically diverse backgrounds. School counselors not only work as leaders, advocates but also as "collaborative team members and supporters of systemic change" (Aydin, 2011, p. 36). Through this renewed leadership between school counselors and principals, it becomes possible to develop a type of working alliance to meet the needs of students from linguistically diverse backgrounds. With this review the author aims to discuss the ways to create a collaborative partnership between school counselors and principals for linguistically diverse students in order to promote their social integration, school achievement and overall well-being. Exploring school counselors' and principals role in creating a welcoming school climate towards linguistically diverse students within the school and school community can promote positive organizational culture. Accordingly, the following topics will be explored and discussed: a) principals influence on school achievement through facilitating a collaborative climate and b) how school counselors facilitate leadership as change agents. Both school principals and school counselors work towards achieving similar goals; thus they can facilitate more collaborative leadership as they reach out to the school community. Using a systemic approach, which generates greater understanding and awareness, school counselors and principles play a critical role in the transformation of their school system. When school counselors and principals join forces, students from linguistically diverse backgrounds learn and achieve better. A collaborative school climate is critical in order to develop a positive organizational school culture, which generates motivations for greater connection among the stakeholders.
\end{abstract}

Key words: school counselor leadership role, collaborative school climate, principal support

\section{Introduction}

The number of non-native speaking students in the American K-12 school system has increased significantly (Araujo, 2009; U.S. Department of Education, 2019, 2020; Fix and Capps, 2005) and is projected to increase by $25 \%$ in 2026 (2002). The number of migrant students is also increasing in the Turkish school system (International Refugee Rights Association Report, 2017). These changing demographics require innovative approaches to school leadership as school counselors and principals collaborate for linguistically diverse students. The purpose of this literature review is to discuss the importance of creating a collaborative partnership among school stakeholders, specifically referring to school counselors and principals useful for linguistically diverse students. When school counselors and principals join forces for linguistically diverse students, they promote their students' social integration, school achievement and overall well-being (Aydin, 2011; Yildiz, 2021).

According to UNCHR (2017), a total of 5 million 380 thousand Syrian citizens have been forced to evacuate from their native country since 2011; and just about 2 million 555 thousand of these migrants consist of children (47.5\%). It is evident that this is not only a migration problem but also a major issue concerning the education of refugee children. While the numbers of diverse students have been increasing in the public school system in Turkey, how to effectively promote a school leadership to meet the needs of students from linguistically diverse backgrounds is not thoroughly explored in research (Allensworth \& 
Hart, 2018; Sağlam and Illksen-Kanbur, 2017). The main purpose of this review is to address the abovementioned gap through unfolding ways for this working alliance as school counselors and principals join forces to create influential leadership dynamics that promote students' school success.

The issues of students with different native languages are complex due to their language problems, cultural adaptation, migration and war-related trauma experiences. As a group with special needs, school counselors have important duties in working with refugee and immigrant students. In order for school counselors to fulfill these tasks effectively, they must have competence in assisting the cultural adaptation process, multicultural counseling, and the trauma process. According to the reports of the United Nations, more than half of the population of Syria (13.5 million people) had to leave their country and take refuge in neighboring countries. Half of those who migrated to other countries are children between the ages of $0-15$. Approximately 1 million people lost their lives and 2 million people were injured in the Syrian civil war (International Refugee Rights Association Report, 2017). However, while 7 million Syrians took asylum within the country, 6.5 million Syrians were forced to seek asylum in other countries. Additionally, it is estimated that more people are victims of the Syrian civil war than are known by official statistics. Immigration Administration General Directorate of the Ministry of Interior (2018) official statistics indicates that the war has been ongoing for 8 years, resulting in 3.6 million Syrians' seeking refuge in Turkey. Syrian refugee children who are victims of war are especially in need of professional help to overcome the adverse effects of both their traumatic life events and to adapt to their new life conditions (Machel, 2001; Akdeniz, 2018).

School counselors have a leadership role within their school community as they act to utilize multiple system of support transforming their schools on behalf of their students' needs. Numerous projects geared toward refugee students are managed by the Ministry of National Education conducted by a collaborative team of school professionals including school counselors as systemic change agents. When the comprehensive curriculum program issued by the Ministry of National Education during the academic year of 2014-2015 resulted an increased access to education nearly five times more compared to the previous year. During the academic year of 2015-2016 after implementing curriculum, nearly $40 \%$ more Syrian refugees were observed to have an access to education (Ateşok, 2018).

A collaborative school climate is essential for developing a positive organizational culture, which creates motives for greater connection within the stakeholders (Hutchins, Greenfeld, Epstein, Sanders, \& Galindo, 2012). They facilitate social and emotional learning in building effective schools. When they work with their principals in creating partnerships, they both influence school achievement through facilitating a collaborative school climate (Aydin, 2011). Specifically focusing on the role of principals, the following section will include discussions on the following topics a) transformative leadership that facilitates collaborative school climate; b) principals influence school achievement through the school climate they cultivate; and c) cross-boundary leaders work with students and their families to connect them with the opportunities and also support them within the school community.

According to the previous research there was a significant positive relationship between school principals' expectations and school counselor involvement in school-family partnerships (i.e., schoolcommunity collaboration, inter-professional collaboration and overall involvement) (Aydin, 2011; Bryan \& Holcomb-McCoy, 2004, 2007). In Bryan and Griffin's (2010) study, school principals' expectations were not related to inter-professional collaboration. Focusing on linguistically diverse families, Aydin's study examined school counselor involvement in the inter-professional collaboration. Findings highlighted the complexity of school, family and community partnerships with linguistically diverse families which are also acknowledged by school counselors. Moreover, school principals' expectations predicted involvement in the regression model (Aydin, 2011). Whenever school counselors and principals collaborate, it benefits linguistically diverse students' wellbeing and school achievement (Aydin, 2011, Yildiz, 2021).

Concerning relevant definition related to the topic as follows: School counselors are licensed professionals whose roles and functions involves in assisting students succeed better academically and also assist students in personal, social and career related matters (ASCA, 2008). Linguistically diverse students are those who speak languages other than English. English Language Learners refers to those students with lower performances in reading and writing with their classmates (NCLB, 2001). As a variable Principal Support is an important that have an effect on school counselor involvement in school, family and community partnerships (Pérusse, Goodnough, Donegan, \& Jones, 2004).

\section{Principals Influence School Achievement through Facilitating Collaborative Climate}

When school principals are supportive of their school community they vicariously facilitate student achievement. Principal support is an important variable, which influences school counselor' involvement 
in partnerships; thus, encouraging school counselors to be more engaged in leadership roles and helping creating a collaborative climate within their school system (Chata \& Loesch 2007; Leuwerke, Walker, \& Shi, 2009; Pérusse, Goodnough, Donegan, \& Jones, 2004; Sanders \& Harvey, 2002). Just as each stakeholder has a personal perception of the school counselor's role within the school, the principal may have a personal vision of how school counselors could be most effective within the school community (Culbreth, Scarborough, Banks-Johnson, \& Solomon, 2005). While school districts and school administrators face meeting students' massive needs and accountability demands, they do not always recognize how the professional role description and training prepares school counselors to respond to social, emotional and career related needs of their students (Adelman \& Taylor, 2002).

In a qualitative study, Amatea and Clark (2005) interviewed 26 school administrators regarding their perceptions on school counselor's role. One fourth of the principals asserted that they viewed the school counselor as their team members in the school administration, who perform administrative tasks as a subordinate rather than a professional. Counselor education programs can provide better opportunities for school counseling students by training them "(a) to view themselves as having a unique skill set needed by the school as a whole, (b) to deliver those skills, and (c) to function as a member of a team of school leaders" (Amatea \& Clark, 2005, p. 25). Furthermore, Janson, Militello, and Kosine (2008) examined perceived professional relationships of school counselors and principals. Using Q methodology to develop 45 opinion statements with 39 professional school counselors and principals about their relationship, four factors emerged. Three of them involved constructive attributes of the school counselor-principal relationship; one factor emphasized interpersonal collaboration. Learning how to influence other school members' expectations is essential. To do this, training programs can foster systemic thinking in relation to school counselors' roles as part of a larger system, which is reciprocally structured and restructured.

Kirchner and Setchfield (2005) assessed the perceptions of school counselors and administrators who had an academic training that focused on understanding of each other's roles. School principals were inclined to accept statements inconsistent with the school counselors' roles. While some literature indicates that school principals advanced their knowledge of school counseling programs through training and research, many principals' perceptions about the school counselors' roles are developed by their own experiences (Coy, 1999). Attaining knowledge related to the operation of school counseling programs with regards to school counselors' roles are not always required during school administration training (Fitch, Newby, Ballestero, \& Marshall, 2001). Therefore school counseling programs are often formed based on minimal education or based on previous experiences (Seashore, Jones, \& Barajas, 2001). It is not always clear what involves the appropriate roles, which can be a concern for partnership practices.

When school counselors serve as liaisons in the school community (Davis, 2005), the principal's support in creating a collaborative school climate becomes critical. In Aydin, Bryan, and Duys's (2012) study, 95 school counselors were asked about their involvement in school, family and community partnerships of working with linguistically diverse families. School counselor perceptions about linguistically diverse families and perceptions of the school principal were significantly correlated, $r=.45 ; p<.01$. More favorable perceptions of the principal were associated with positive attitudes toward linguistically diverse families. Perceptions of partnerships with linguistically diverse families and perceptions of the school principal were also significantly correlated, $r=.51 ; p<.01$. When school counselors had more favorable perceptions of their principals, they were more inclined to hold positive attitudes toward partnerships with linguistically diverse families. Both perceptions about school climate and the school principal were significantly correlated, $r=.72 ; p<.01$. When school counselors hold more favorable perceptions of their principal they tend to hold positive perceptions about the school climate.

School counselor and school administrators have separate roles and responsibilities. However, the common goals they share complement each other specifically to ensure what is best for their students. Overlapping roles and responsibilities assure that they join their forces for the benefit of their students and the school community. Any activity not directly related to instruction is viewed by school principals and policy makers to be taking resources away since they believe schools' primary mission is teaching (Adelman \& Taylor, p. 236), thus, creating challenges for school, family and community partnerships. If school counselors and principals join together for leadership and advocacy, this can have a positive influence for a school's mission, climate, and students' capacity to achieve academic success (Stone \& Clark, 2001). Principals' expectations in creating a collaborative school climate are critical. Written comments that school counselors offered persistently accentuated the importance of principal expectation as an important predictor for their collaborative partnerships in the school community (Aydin, 2011; Bryan \& Holcomb-McCoy, 2004, 2006; Bryan \& Griffin, 2010).

The importance of principal expectations on school counselors' role and school, family and community partnership activities is acknowledged in the literature (Aydin, 2011; Amatea \& Clark, 2005; Finkelstein, 2009; Janson, Militello, \& Kosine 2008; Kirchner \& Setchfield, 2005). Previous research pointed that 
principal expectation was related to school counselors' involvement in partnerships (Bryan \& Griffin, 2010). In addition, principal expectations appeared to predict school counselors' involvement in several dimensions: school-home partnerships, school-community collaboration, and overall partnership involvement, except involvement on collaborative teams. School counselors reported a moderate level of involvement on all three dimensions as well as overall involvement. Principal expectations were the strongest predictor of these types of partnership involvements (Bryan \& Griffin, 2010).

The above mentioned reasons underline the importance of principal expectations as a significant variable that predict school counselors' involvement in school, family and community partnerships with linguistically diverse families. Studies highlight that principals' expectations were related to school counselors' involvement in partnerships. Of interest is whether school counselor involvement in school, family and community partnerships with linguistically diverse families relates to principal expectations using a nationally representative sample of participants (Aydin, 2011; Yildiz, 2021).

\subsection{Transformative leadership facilitates collaborative school climate}

Leadership in the school context embodies collaborative efforts of educators holding shared goals of student attainment. In this context, leadership is a mindset which affects the way a school counselor approaches work related interactions with staff and the perceived influence (Mason, 2008). Stone and Dahir (2006) suggest that school counselor leadership has a bearing on positive student outcomes: "The leadership mindset means that the school counselor, along with colleagues who embrace leadership, views his or her position in the school as critical in supporting indicators of student success ..." (p. 94).

Northouse (2004) stated "leadership is a process whereby an individual influences a group of individuals to achieve a common goal" (p. 3). This definition comprises the followings, which are common among leadership theories, i.e. leadership (a) is a process; (b) is about influence; (c) happens in a group context; and (d) comprises accomplishing goals (p. 3). Among leadership theories transformational leadership approach appears to be aligned with reforms and movements that took place in school counseling (Northouse, 2004). Transformational leadership allows the leader and group members to share power where they work to achieve a continuous, comprehensive transformation beyond completing the individual task. Thanks to strong charismatic and visionary appeal, the leader strategically uses relationship variables within the group to encourage desired results. According to Northouse (2004), transformational leaders are renowned as change agents,

...who are good role models, who can create and articulate a clear vision for an organization, who empower followers to achieve a higher standard, who act in ways that make others want to trust them, and who give meaning to organizational life. (p.198)

What is transformational leadership? As one of the most prominent approaches among the leadership theories of the last several decades, it is a form of leadership, which involves inspiring others to the vision and aim of the organization. Followers are challenged to be innovative leaders as they coach, mentor, challenge and support (Bass \& Riggio, 2006). Transformational leadership approach embraces school counselors' role as collaborative school change agents who advocate to use comprehensive program for positive student outcomes. Most of the literature suggests the transition from an acquainted concept of leadership position to a process, from an individual practice to a set of skills embodied by a community of individuals who hold leadership positions (Katzenmeyer \& Moller, 2001; Northouse, 2004; Slater 2005). Through utilizing the following dimensions: a) charismatic or inspirational influence, b) inspirational motivation, c) stimulation and d) personalized thinking (Judge \& Piccolo, 2004) transformational leadership is effective in affecting employee performance and other outcomes (Judge \& Piccolo, 2004; Farahnak, Ehrhart, Torrews, \& Aarons, 2020). Transformational leadership includes various emotional domains associated with leadership behavior, including appealing to followers on an emotional level, inspiring them to act, and taking into account the needs of followers. Such behaviors are geared towards enhancing others and are not necessarily geared towards leaders' his or her own emotional needs.

Moreover, transformative leadership facilitates a collaborative school climate. Social-emotional skills are essential ingredients for success in life and can be attained in school. Elias, O'Brien and Weissberg, (2006) examine transformative leadership from the perspective of social and emotional learning. They argue that now, school administrators desire to see schools as exciting places for students and the school community where both academic and social-emotional learning are carried together (Elias, O'Brien, \& Weissberg, 2006). Transformative leadership requires accomplishing this. Transformative leaders recognize each stakeholder's role within the school community (i.e., students, teachers, parents, and community) in keeping their schools up-to-date. Transformative leadership involves embracing many tasks; therefore, leadership must be shared, as each school professional would realize how each layer of leadership touches 
everyone who holds responsibility toward students. Principals have designated roles in identifying the agenda for leadership and motivating others to share their vision.

How could one integrate schoolwide transformative leadership principles for social-emotional learning (SEL)? While every school uses various ways to integrate social and emotional learning into academics, the school leadership approach is important to implement, maintain and coordinate. These starting points include: a) "Create organizing and unifying themes, values, and visions for your school; b) Involve students in integrative service-related projects; c) Implement skill-building curricula that are linked to existing school subject areas; d) Infuse SEL into existing academic subjects" (Elias, O'Brien, \& Weissberg, 2006, p. 12). These activities can be conducted through counseling and guidance activities by school counselors.

\subsection{Principals influence school achievement through the school climate they cultivate}

School principals influence student achievement. Principals influence school achievement primarily over the changes they create in their school climate. Allensworth \& Hart (2018) examined school principal related factor's role on student achievement. Principals are generally viewed as the primary change agents to increase student success. Therefore, their role is multifaceted, and there are various ways that principals impact teaching and learning. What matters most regarding principle related factors? To answer this question the authors used data from many schools to learn how principals' role in students' higher learning outcomes on standardized achievement tests. Researchers also visited 12 schools, to interview principals and teachers so that they could study what was being done by principals, regarding achievement results (i.e., what types of actions improve what types of actions does not).

The study used both quantitative and qualitative data. The quantitative part of the study included district wide data on all Chicago public schools and surveys that contain student and teacher experiences, student test results. Qualitative parts of the study included 12 schools, which were used as case study schools (i.e., with strong or improving leadership); neighborhood schools with high level free and reduced priced lunch rates. Findings indicated that a) through fostering strong learning climates, principals have the utmost influence on student learning and b) principals create a strong learning climate when they support educators' leadership on comprehensive goals of their schools. An important outcome that emerged was that schools with the highest learning gains had principals who promoted a strong school climate, through empowering and coordinating teachers and school staff around shared goals. Another important implication indicated that improvements in the school climate, promotes success amongst teachers and students. Successful principals are skilled in organizing and supporting shared leadership among their staff. Principals empower teachers and school staff to foster collective ownership for the vision of their schools. They manage shared leadership by guiding, coordinating, and monitoring the work of teachers and leaders in the school (Allensworth \& Hart, 2018).

\subsection{Cross-boundary leaders connect students and their families to the opportunities and support within their school community}

A report by Blank, Berg \& Melaville (2006) with 11 public school community profiles showed the effectiveness of cross-boundary leadership for large-scale, community-wide education reform strategies used in an extensive community contexts (i.e., the smallest district had 2,100; the largest had 400,000 students). The study utilized school achievement data and comparison achievement data (i.e., from schools not part of this effort), surveys, and interviews. Public school community profiles described partnerships as taking place between schools and community groups where the resources are directed to foster student learning. Cross-boundary leaders who promote this process come from schools, local administration, health services, social services, community organizations, businesses, family support groups, youth development agencies, higher education, civic groups and faith-based groups. Using the designated schools' program evaluations, a report emerged which described these efforts:

Cross-boundary leaders understand that educating young people to high standards means connecting children and families to sources of opportunity and support in their community. It means welcoming the rich diversity in language, culture, and outlook that changing student populations bring to schools and refusing to evade the challenges posed by race, equity, and poverty issues. Making the best use of all their community assets, these leaders are scaling up their efforts to create a substantial number of community schools as quickly as possible, following a powerful vision with a clear focus on results (Blank, Berg \& Melaville, 2006, p. v). 
Blank, Berg \& Melaville (2006) stated "Using public schools as the hub, community schools knit together inventive, enduring relationships among many partners who contribute expertise and resource for effective learning environments" (p. 2). Furthermore, school counselors play a critical role in creating a collaborative school atmosphere amongst shareholders using connections for partnership within the multicultural school community (Betters-Bubon \& Schultz, 2017; Epstein \& Van Voorhis, 2010; Evans, Zambrano, Cook, Moyer, and Duffey, 2011; O'Donnell \& Kirkner, 2014). It is critical that school counselors deliver culture-sensitive school counseling programs (Dahir \& Stone, 2011; Hutchins, Greenfeld, Epstein, Sanders, \& Galindo, 2012; Grothaus, 2012), to create an all-inclusive learning community. There are many reasons to invest in developing school, family and community partnerships through school programs and school climate, providing family services and support with the aim of fostering connections with families in the school and community, developing parental skills and helping teachers (Epstein, 1995, p. 701). Specifically focusing on the role of school counselors facilitating leadership as change agents, the following section will focus on: a) commitment to collaborative school climate requires responding to language barrier; b) commitment to collaborative school climate requires to engage in an ongoing training; and c) commitment to collaborative school climate requires to engage in multitier system of supports.

\section{How School Counselors Facilitate Leadership as Change Agents}

A collaborative, systemic approach is a professional commitment for school counselors to work with others professionals in their school to engage in family involvement activities. The role of school counselors as leaders in their school, advocates for students and their families, collaborative team members within their school system and in the school community, and also their roles as systemic change agents are promoted by current movements and reforms (e.g., The ASCA National Model, 2005, 2012, 2019). School counselors are in a great position to promote family involvement practices because of their curricular training in counselor preparation programs specifically focusing on human development, human psychology, collaboration skills and supportive services, and in systems change.

\subsection{Commitment to collaborative school climate requires responding to language barrier}

Shortage of bilingual staff members in school hinders access to reach out to LDS and their families; thus, there is a need for an increased number of bilingual school counselors. School counselors used interpreters more often as the number of linguistically diverse students increased (Aydin, 2011; Dogan, 2017). A rising number of linguistically diverse students and the shortage of bilingual school professionals are currently being acknowledged in the literature. Because linguistically diverse students' needs often go unmet in counseling, due to language barriers, school counselors' training programs should address this issue (Paredes, 2010). Also, shortage of bilingual school staff hinders linguistically diverse families' ability to be involved in the school and school community (Chavkin \& Gonzalez, 1995). These facts call school counselors for to engage in taking a leadership role in creating a collaborative school climate.

In Aydin's study with 916 school counselors in America, nearly one-fifth of the participants $(17.6 \% ; 152)$ stated that they were bilingual or multilingual, while the majority $(82.2 \% ; 712)$ stated that they were not. The bilingual status of the counselors in school and the use of interpreters were associated to their general engagement and also involvement in partnerships with linguistically diverse students. The approximate total number of enrolled English language learners averaged 214 (SD = 477), revealing that one out of every four enrolled students is linguistically diverse. Given the descriptive statistics for the approximate total number of enrolled students ( $M=905$; $S D=723)$, about half of the students $(M=370$; SS $=575$ ) were typically enrolled on free and reduced priced lunch programs (Aydin, 2011).

Do school counselor variables (the use of interpreters and bilingual status) predict involvement in school and community partnerships with linguistically diverse families? Aydin (2011) investigated to what degree the use of interpreters, bilingual status, caseload, race and ethnicity, and free and reduced priced lunch status correlated with the percentage of linguistically diverse students. The ANOVA test showed important results that the use of interpreters was influenced by the percentage of linguistically diverse students. School counselors used interpreters more often when they had increased number of linguistically diverse students. Furthermore, there was a meaningful relationship between percentages of linguistically diverse students served and free and reduced priced lunch status, caseload, bilingual status, and race and ethnicity. When school counselors had a larger percentage of linguistically diverse students, they tended to have a larger number of students on their caseloads, when they were bilingual or 
multilingual, coming from a diverse background having a different background, and having a higher number of students on free and reduced priced lunch status.

Counselor education programs and professional organizations need to emphasize training bilingual school counselors. Communication may be a barrier for a majority of monolingual school counselors (82.2\%; corresponding to 712 participants), highlighting an apparent need for bilingual school counselors (Aydin, 2011). Lately, school counseling programs are offering specializations and certificates in bilingual school counseling (e.g., Brooklyn College, St. John's University, Mercy College, NYU Steinhardt School of Culture) (Paredes, 2010). Efforts to encourage bilingual and multilingual individuals in the school system should be supported. Counselor education and counselor training programs in Turkey should consider training Arabic speaking candidates in teaching, school and mental health counseling and administration. Through the Department of Education, Turkish Ministry of National Education is implementing a project titled "Project on Promoting Integration of Syrian Kids into the Turkish Education System." The main purpose of PIKTES is to encourage the accessibility of kids to education in Turkey who are under provisional protection while also promoting their social integration within the school community. Another central mission of this exemplary project is to work closely in conjunction with the Ministry of National Education. With this purpose the aim is to both realize educational goals and assist refugee students who are under provisional protection to accommodate to the educational community.

The research conducted by Sarıtaș, Şahin, and Çatalbaş (2016) revealed that the most common problem faced by primary school teachers and administrators with refugee students was the language barrier. Regarding the solution of the problems faced by the teachers and administrators working with refugee students the following opinions were expressed: providing pre-school education, giving these family and students language education, providing education in the same class with other students to protect them against discrimination and labeling and opening a designated unit under the auspices of the Directorate of National Education. Solak and Çelik (2018) conducted a study aimed to determine language-related problems of refugee students who have migrated to Turkey at the elementary school level. This qualitative study included fifteen refugee students attending two primary schools in Ankara. Five Syrian, three Iraqi, three Afghanistan, two Somali, one Libyan and one Iranian student were interviewed along with ten teachers. The results revealed that students who were not subject to the language preparation process and started school without addressing the language barrier face social and academic issues. These students are unable to progress academically because they do not understand the lessons taught at school (Solak \& Çelik, 2018) and also socially because of the inability to communicate with their peers (MercanUzun \& Bütün (2016) both of which may negatively affect their future success (Solak \& Çelik, 2018). Language barriers of refugee students emerge as a serious obstacle in their education.

\subsection{Commitment to collaborative school climate requires to engage in an ongoing training}

Pledging to create a collaborative school climate requires all educators to be in an ongoing training. There are professional development needs and multicultural competency skills training of school counselors for responding to diverse students' needs. Given the rapid increase in linguistically diverse students in K-12 school settings, there are not many studies focusing on the educational and professional development needs of school counselors (e.g. McCall-Perez, 2000; Schwallie-Giddis, et. al., 2004; Paredes, 2010). In 2012, Aydin, Bryan, and Duys conducted a survey study with 95 school counselors in Iowa, findings indicated that $74 \%$ of the participants received between 0 - 10 hours of training in partnership.

Training is an important variable, influencing school counselors' leadership role in creating collaborative school climates. Aydin's (2011) national study with 916 school counselors showed that approximately $40 \%$ of the participants received less than 10 hours of general training in school, family and community partnerships practices. In addition, nearly half of the participants stated having not been trained in school, family and community partnerships specific to working with linguistically diverse students and families. This finding underlines the need for school, family and community partnership training particularly in working with linguistically diverse families. Similarly, in a study by Paredes (2010), with 601 school counselors using the School Counselor Self-Efficacy (SC-SELL) scale with ELLs; while working with linguistically diverse students, the vast majority of the participants stated that their professional development needs were not being sufficiently met. Conversely, when school counselors had linguistically diverse students in their schools, they did not mind having more students in their caseload.

The attitudes and perceptions of educators and administrators influence their work as they attend to the needs of refugee students who are under provisional protection in Turkish schools. A qualitative study conducted by Sakız (2016) examined the thoughts, beliefs and attitudes of 18 school administrators on the inclusion of linguistically diverse Syrian refugee students who are under provisional protection in 
Southeastern Anatolia Region schools. During their interview, participants emphasized that when educating children, teachers should be provided additional training to increase their professional competency and also to help them most effectively engage with students from diverse backgrounds and various conditions. Another qualitative study conducted by Mercan-Uzun and Bütün (2016) interviewed six pre-school teachers. These educators who had refugee students who are under provisional protection in their classes stated that they felt inadequate in solving problems and did not know how to help these children because they had not worked with refugee students before. Teachers stated that refugee students could not communicate with their peers and teachers because they did not speak Turkish and as a result they felt alienated. Preschool teachers stated that they had difficulty supporting these students. Eventually, language issues make it difficult for refugee students who are under provisional protection to develop a sense of belonging. According to school administrators teachers had difficulties in identifying problems of refugee students who are under provisional protection (Eroğlu \& Gülcan, 2016). Balkar, Şahin, and Işıklı- Babahan (2016) stated that teachers felt inadequate in classroom discipline and needed professional / in-service development. Similarly, Taştekin, Bozkurt-Yükçü, İzoğlu, Güngör, Işık Uslu, and Demircioğlu (2016) found that teachers have a positive attitude towards multiculturalism, but in their classroom practices they reported that they did not feel competent due to factors such as a) family members' approaches; b) attitudes of school administrators; c) deficiencies in the curriculum and d) not having sufficient knowledge about multiculturalism. Partnerships with stakeholders are very essential to work with linguistically diverse students and families (Aydin, 2011; Davis, 2005).

Having the experience to work with linguistically diverse students may help increase educators' level of knowledge, awareness and skills. Saglam and Ilksen-Kanbur (2017) conducted a study to examine the attitudes of classroom teachers towards refugee students in Turkey. They developed the "Refugee Student Attitude Scale (RSAS)" which included three sub-dimensions and 24 items. The three sub-dimensions of the scale were communication, adaptation and efficiency. The scale was completed by 501 classroom teachers (53\% female; 47\% male) working in Northeastern Turkey during the 2016-2017 academic year. Results found teachers' competence towards teaching refugee students predicted by gender as men felt more competent than women. Moreover, results revealed that teachers showed a more positive attitude if there was a refugee student in their class, indicating the role of exposure to the needs of linguistically diverse students has helped increase teachers' awareness and understanding. In short, school professionals' attitudes influence students' learning experience (Allensworth \& Hart, 2018). All of the above-mentioned reasons, school, family and community partnerships with stakeholders in order to create collaborative school climate are very critical for school professionals to work with linguistically diverse students and families (Aydin, 2011, Davis \& Lambie, 2005; Davis, 2005).

\subsection{Commitment to collaborative school climate requires to engage in multitiered system of supports}

When school counselors and principals join forces, students from linguistically diverse backgrounds learn and achieve better. A collaborative school climate is critical in order to develop a positive organizational school culture, which generates higher levels of motivations for greater connection among the stakeholders (Hutchins, Greenfeld, Epstein, Sanders, \& Galindo, 2012). Multitiered system of supports (MSSS) is a culturally responsive, evidence-based model used in grade schools that integrate data-based strategies for problem solving. When academic content, behavioral responses and interventions tackled at tiered both the learning outcome and social-emotional functioning become stronger of all students (Sink, 2016). Moving forward by student related data, school counselors and principals join forces as MTSS teams that involve circular data-based problem solving approach. Thus, they have the renewed opportunities to make more sensible decisions both for general population and also for other students with diverse educational needs. MSSS approach assists furthering to generate more integrated all-in-one system of curricular instruction and behavioral intervention (Ehren, Montgomery, Rudebush, \& Whitmire, 2006). When school professionals operate from the MTSS perspective, they have the opportunity to further the long-term effect on students academically and behaviorally (Ziomek-Daigle, Goodman-Scott \& Donohue, 2016). The implementation of MTSS lines up with the role of school counselors as leaders in their school system. They advocate for students and their families, collaborative their team members within the school system mainly with the school management (The ASCA National Model, 2005, 2012, 2019). As a result, according to the ASCA National Model, school counselors facilitate systemic interventions when they carry out their role of school counseling at any grade level which can be used across various domains (i.e., for example academic, career and social and emotional development) (Hatch, Duarte, \& Degregorio, 2017). As a key player within the school system, school counselors engage in the 
abovementioned practices and join their forces with the school administration, which in turn influences students' achievement (i.e., through facilitating collaborative school climate) (Aydin, 2011; Yildiz, 2021).

\section{Implications}

According to Bryan and Griffin (2010), school factors (i.e., collaborative climate and principal expectations) are related to participation. A number of school and school counselor-related factors (e.g. principal support, principal expectations, collaborative school climate, time constraints, lack of resources, attitudes about families) influence participation in community partnerships with school, family, and linguistically diverse families (e.g. Bryan, 2005; Griffin and Steen, 2010). The effectiveness of school, family, and community partnerships for students' success has been emphasized by many researchers. However, numerous barriers for families are hinder effective school, family and community partnerships. Lack of trust for participation, and socioeconomic, cultural or linguistic barriers hinder involvement. School professionals may have inadequate information or misconceptions about families, insufficient training. Understanding barriers to the school counselor's participation in linguistically diverse families should be investigated in future research to overcome them (Aydın, 2011).

Aydin's (2011) study calls attention to the complexity of involvement in school, family and community partnerships with linguistically diverse families. General factors account for $70 \%$ of variance, while unexplained effects account for $22 \%$ in psychotherapy outcome, signifying that counselor training should focus on utilizing common factors (e.g., building a stronger alliance) to facilitate results [involvement] (Wampold, 2001; Wampold, \& Imel, 2015). Aydin (2011)'s study working with linguistically diverse families offers critical information on how achievement gaps can be narrowed. It contributes to the literature by offering a further understanding for school counselors and counselor educators on whether school and school counselor-related factors may help or hinder involvement in SFC partnerships. The number of school and school counselor-related factors (e.g., principal support principal expectations, collaborative school climate, time constraints, lack of resources, attitudes about families) influence involvement in school, family and community partnerships with linguistically diverse families.

There is a need for an increased number of bilingual school counselors. Since language may be a barrier for monolingual school counselors working with linguistically diverse students, it is crucial to recruit bilingual individuals in the field (Paredes, 2010). While in some occasions linguistically diverse students may have adequate English proficiency skills to communicate in school; their emotions might be more accurately and eloquently communicated in their native languages (Acevedo, Reyes, Annett, \& Lopez, 2003). Thus, school counselor training programs should encourage learning another language. No wonder why the U.S. Surgeon General highlights the importance of having bilingual mental health care-givers.

\section{Limitations and Conclusion}

One of the major limitations for serving linguistically diverse students is caused by language barrier. In the literature, it is widely recognized that linguistically diverse students struggle due to language issues. Moreover, they may have difficulties expressing themselves for multiple reasons; for example, they may not know the language well enough, they may have a trauma experience caused by the war and they may experience developmental differences in their classroom since learning a language may delay their education. Language barrier may also lead to emotional challenges such as anger and aggression. Due to these challenges linguistically diverse students resort to violence and crime (i.e., often getting involved in disciplinary acts). School professionals may handle behavioral problems to overcome these limitations by providing in-class activities such as "Don't be a bully, be a friend", offering seminars on peer bullying and individual sessions that inform these students about school rules and culture and by providing a greater understanding on the fact that war feeds on violence (Cin, 2018; Günlü, Sağlam, Gürat, \& Uz, 2020).

The literature reviewed indicates that school counselors have a leadership role in creating a collaborative school climate. Joining forces with the school principal would be of great benefit to students' school success and overall well-being, specifically students from linguistically diverse backgrounds. School counselors promote stronger collaboration with their school principals through engaging families to community resources for support and facilitating learning in building effective schools. When they facilitate family engagement and partnership with linguistically diverse families, they act as systemic change agents; thus these efforts transform their schools. Commitment to collaborative school climate requires school counselors to engage in an ongoing training to meet the needs of diverse student populations, including responding to language barrier (Gencer, 2017; Sağlam \& İlksen-Kanbur, 2017). Briefly, school counselors, together with their principals, must invest in to create supportive communities, effective schools and strong families for linguistically diverse students. 
Providing trauma education to school professionals, increasing parental engagement, providing language training to enable students to express themselves, and raising awareness of refugee students about Turkish school culture are among the solutions that is offered to address these limitations. It is noted that refugee students, who have difficulty in adapting, often have language problems that cause them to group with their friends from their own culture. Practicing inclusive education and social activities where Turkish and refugee students socialize may prevent groupings. Responding to the needs of these linguistically diverse students, in-service training practices and College of Education curriculum should be revised and reviewed (Günlü, Sağlam, Gürat, \& Uz, 2020; Sağlam \& İlksen-Kanbur, 2017).

There are nearly 35 thousand counselors in Turkey and $95 \%$ of these graduates are employed in the Ministry of National Education as school counselors. Nearly 16.000 undergraduates from various counseling programs are currently looking for opportunities to be hired in schools. In this context, in line with the 2023 vision of the Ministry of National Education, many reforms are needed in the field of school counseling (Turkish PDR, 2019). When school counselors and principals join forces, they promote their students' social integration, school achievement and overall well-being (Allensworth \& Hart, 2018).

Moreover, when school counselors and principals join forces, students from linguistically diverse backgrounds learn and achieve better. Focusing the role of principals the following topics are explored; a) transformative leadership that facilitates collaborative school climate; b) principals influence school achievement through the school climate they cultivate; and c) cross-boundary leaders work with students and their families to connect them with the opportunities and also support them within the school community. Moreover, focusing on the role of school counselors facilitating leadership as change agents, the following topics are discussed; a) commitment to collaborative school climate requires responding to the language barrier; b) commitment to collaborative school climate requires engagement in an ongoing training; and c) commitment to collaborative school climate requires engagement in multitier system of supports. It is critical to create a collaborative school climate where school counselors and principals join forces to develop a positive organizational school culture for greater connection among the stakeholders.

\section{References}

Acevedo, M. C., Reyes, C. J., Annett, R. D., \& Lopez, E. M. (2003). Assessing language competence: Guidelines for assisting persons with limited English proficiency in research and clinical settings. Journal of Multicultural Counseling and Development, 31, 192-204.

Adelman, H. S., \& Taylor, L. (2002). School counselors and school reform: New directions. Professional School Counseling, 5, 235-247.

Akdeniz, Y. (2018). Türkiye'de Yaşayan Suriyeli Mülteci Öğrencilerin Uyum Sorunları: Şanlıurfa Örneği. Yüksek Lisans Tezi. Sakarya Üniversitesi. Eğitim Bilimleri Enstitüsü.

Allensworth, E. M., \& Hart, H. (2018). How do principals influence student achievement? Chicago, IL: University of Chicago Consortium on School Research.Retrieved from: https://consortium.uchicago.edu/publications/how-do-principals-influence-student-achievement

American School Counseling Association (2008). American School Counseling Association. Retrieved from the ASCA Web site: www.schoolcounselor.org/content.asp? contentid=389

American School Counselor Association (2005, 2012, 2019). ASCA National Model: A framework for school counseling programs (3rd ed.). Alexandria, VA: Author.

Araujo, B. E. (2009). Best practices in working with linguistically diverse families. Intervention in School and Clinic, 45(2), 116-123.

Ateşok, Z. Ö. (2018). Karşılaştırmalı perspektiften uluslararası mülteci rejimi bağlamında mülteci eğitimi ve Türkiye örneği. Doktora tezi. İstanbul Üniversitesi, İstanbul.

Aydin, N.G. (2011). A national study: School counselor involvement in school, family and community partnerships with linguistically diverse families. Saarbrücken, Germany: Lambert Academic Publishing.

Aydin, N.G., Bryan, J. A. \& Duys, D.K. (2012). School counselors' partnerships with linguistically diverse families: an exploratory study. The School Community Journal, 22(1). 145-166.

Balkar, B., Şahin, S. ve Işıklı-Babahan, N. (2016). Geçici eğitim merkezlerinde (GEM) görev yapan Suriyeli öğretmenlerin karşılaștıkları sorunlar. Eğitimde Kuram ve Uygulama,12(6), 1290-1310.

Betters-Bubon, J. \& Schultz, J. (2017). School counselors as social justice leaders: An innovative schoolfamily-community partnership with latino students and families. Professional School Counseling. 21. 2156759X1877360. 10.1177/2156759X18773601.

Blank, M. J., Berg, A. C., \& Melaville, A. (2006). Growing community schools: The role of cross-boundary leadership. Washington, DC: Coalition for Community Schools. 
Bryan, J. A. (2005). Fostering educational resilience and achievement in urban schools through schoolfamily community partnerships: School counselors' roles. Professional School Counseling, 8, 219227.

Bryan, J. A., \& Griffin, D. (2010). A multidimensional study of school-family-community partnership involvement: School, school counselor, and training factors. Professional School Counseling, 14(1), 75-86.

Bryan, J. A., \& Holcomb-McCoy, C. (2004). School counselors' perceptions of their involvement in schoolfamily-community partnerships. Professional School Counseling, 7, 162-171.

Bryan, J. A., \& Holcomb-McCoy, C. H. (2006). School counselors' training and involvement in school-familycommunity partnership roles: An exploratory study. Journal of School Counseling, 4(13). Retrieved from http://www.jsc.montana.edu/pages/articles.html

Bryan, J. A.,\& Holcomb-McCoy, C. (2007). An examination of school counselor involvement in schoolfamily-community partnerships. Professional School Counseling, 10(5), 441-454.

Bryan, J., \& Henry, L. (2008). Strengths-based partnerships: A school-family-community partnership approach to empowering students. Professional School Counseling, 12, 149-156.

Chata, C. C., \& Loesch, L. C. (2007). Future School Principals' Views of the Roles of Professional School Counselors. Professional School Counseling, 11(1), 35-41.

Chavkin, N. F., \& Gonzalez, D. L. (1995). Forging partnerships between Mexican American parents and the schools. Charleston, WV: ERIC Clearinghouse on Rural Education and Small Schools. (Eric Document Reproduction Service No. ED388489)

Cin, G. (2018). Suriyeli öğrencilere eğitim veren sınıf öğretmenlerinin yaşadıkları sorunlar ve psikolojik sağlamlılık düzeyi: Adana İli örneği. Master Tezi, Çağ Üniversitesi Sosyal Bilimler Enstitüsü.

Coy, D. R. (1999). The role and training of the school counselor: Background and purpose. National Association of Secondary School Principals, 83(603), 2-9.

Dahir, C. (2000). Principals as partners in school counseling. ASCA Counselor, 38, 13.

Dahir, C., \& Stone, C. (2011). The transformed school counselor (2nd ed.). Belmont, CA: Brooks/Cole, Cengage Learning.

Davis, K. M., \& Lambie, G. W. (2005). Family engagement: A collaborative, systemic approach for middle school counselors. Professional School Counseling, 9(2), 144- 151.

Davis, T. E. (2005). Exploring school counseling: Professional practices and perspectives. Boston, MA: Houghton Mifflin Company.

Dogan, S. (2017). School Counselors' Work with Immigrants: A Phenomenological Study of Competence, Social Justice, and Family Language Policy. (Electronic Thesis or Dissertation). Retrieved from https://etd.ohiolink.edu/

Ehren, B., Montgomery, J., Rudebusch, J., \& Whitmire, K. (2006). New roles in response to intervention: Creating success for schools and children. Retrieved from https://www.asha.org/uploadedFiles/slp/schools/prof-consult/rtiroledefinitions.pdf

Elias, M. J., O'Brien, M. U., \& Weissberg, R. P. (2006). Transformative leadership for social and emotional learning. Principal Leadership, 7, 10-13.

Epstein, J. L. (1995). School/family/community partnerships: Caring for the children we share. Phi Delta Kappan, 76(9). 701-712. Doi: EJ502937.

Epstein, J., \& Van Voorhis, F. (2010). School counselors' roles in developing partnerships with families and communities for student success. Professional School Counseling, 14, 1-14. doi:10.5330/prsc.14.1.m6070358408g9227

Eroğlu Ö. B. ve Gülcan, G. M. (2016). Göçle gelen ailelerin ve çocuklarının eğitim sorunları (Mersin İli Örneği). K. Beycioğlu, N. Özer, D. Koşar, İ. Şahin (Ed.), Eğitim Yönetimi Araştırmaları içinde (ss. 219238). Ankara: Pegem Akademi. 1. Baskı. DOI: 10.14527/978-605-318-393-8.

Evans, M. P., Zambrano, E., Cook, K., Moyer, M., Duffey, T. (2011). Enhancing school counselor leadership in multicultural advocacy. Journal of Professional Counseling, Practice, Theory, \& Research, 38, 52-67.

Finkelstein, D. (2009). A closer look at the principal-counselor relationship: A survey of principals and school counselors. Washington, DC: College Board. Retrieved from http://professionals.collegeboard.com/profdownload/ a-closer-look.pdf

Fitch, T. J., \& Marshall, J. L. (2004). What counselors do in high-achieving schools: A study on the role of the school counselor. Professional School Counseling, 7(3), 172-178.

Fix, M., \& R. Capps. "Immigrant Children, Urban Schools, and the No Child Left Behind Act," Migration Information Source (November 1, 2005). http://www.migrationinformation.org/Feature/display.cfm?id=34

Garcia, E. (2002). Student cultural diversity: Understanding and meeting the challenge (3r.ed.). New York, NY: Houghton Mifflin Company. 
Gencer, T. E. (2017). An Evaluation of the Relationship of Immigration and Education: Education Needs of the Syrian Refugee Children and Challenges of Exposed Delays in Schooling Processes. The Journal of International Social Research, 10(54), 838-851.

Göç İdaresi Genel Müdürlügü. (2018). http://www.goc.gov.tr/icerik6/gecicikoruma_363_378_4713_icerik Erişim tarihi: 30 Aralık 2018.

Griffin, D., \& Steen, S. (2010). School-family-community partnerships: Applying Epstein's theory of the six types of involvement to school counselor practice. Professional School Counseling, 13(4), 218-226.

Günlü, A., Sağlam, A., Gürat, C., \& Uz, A. (2020). Okul psikolojik danışmanlarının mülteci öğrencilere yönelik olarak sundukları hizmetlerin değerlendirilmesi. Mehmet Akif Ersoy Üniversitesi Eğitim Fakültesi Dergisi, 55, 168-205.

Hatch, T., Duarte, D., \& DeGregorio, L. (2017). Hatching results for elementary school counseling: Implementing core Curriculum and Other Tier One Activities. Thousand Oaks, CA: Corwin/Sage.

Hutchins, D. J., Greenfeld, M. D., Epstein, J. L., Sanders, M. G. \& Galindo, C. L. (2012). Multicultural partnerships: Involve all families. New York: Eye on Education.

International Refugee Rights Association (2017). Violations in Syria and Aleppo report. Istanbul: INSAMER Humanitarian and Social Research Center.

Janson, C., Militello, M., \& Kosine, N. (2008). Four views of the professional school counselor-principal relationship: A Q-Methodology study. Professional School Counseling, 11(6), 353-361.

Kirchner, G., \& Setchfield, M. S. (2005). School counselors' and school principals' perceptions of the school counselor's role. Education, 126(1), 10-17.

Leuwerke, W. C., Walker, J., \& Shi, Q. (2009). Informing Principals: The Impact of Different Types of Information on Principals' Perceptions of Professional School Counselors. Professional School Counseling, 12(4), 263-271.

Machel, G. (2001). The Impact of War on Children. London: Hurst \& Co.

McCall-Perez, Z. (2000). The counselor as advocate for English language learners: An action research approach. Professional School Counseling, 4, 13-22.

Mercan-Uzun, E. M. ve Bütün, E. (2016). Okul öncesi eğitim kurumlarındaki Suriyeli sığınmacı çocukların karşılaştıkları sorunlar hakkında öğretmen görüşleri. Uluslararası Erken Çocukluk Eğitimi Çalıșmaları Dergisi, 1(1),72-83.

No Child Left Behind Act of 2001, Pub. L. No. 107-110, § 1208, 115 Stat. 1549-1551; § 3102, 115 Stat. 1690-1691, (2002). Retrieved from http://www.ed.gov/policy/elsec/leg/esea/02index.html

O’Donnell, J., Kirkner, S. L. (2014). The impact of a collaborative family involvement program on Latino families and children's educational performance. School Community Journal, 24, 211-234.

Paredes, M. A. B. (2010). Addressing the professional development awareness needs of school counselors regarding English Language Learners (ELLS): Using the School Cultural Capital Game to enhance level of self-efficacy with ELLs and attitudes toward immigrants. Ph.D. dissertation, The University of North Carolina at Greensboro, North Carolina.

Pérusse, R., \& Goodnough, G. E. (2001). A comparison of existing school counselor program content with the Education Trust initiatives. Counselor Education \& Supervision, 41, 100-110.

Pérusse, R., Goodnough, G. E., Donegan, J., \& Jones, C. (2004). Perceptions of school counselors and school principals about the National Standards for school counseling programs and the Transforming School Counseling Initiative. Professional School Counseling, 7(3), 152-161.

Sağlam, H. I. ve İlksen-Kanbur, N. (2017). Sınıf Öğretmenlerinin Mülteci Öğrencilere Yönelik Tutumlarının Çeşitli Değişkenler Açısından İncelenmesi. Sakarya University Journal of Education, 7(2), 310-323.

Sakız, H. (2016). Göçmen çocuklar ve okul kültürleri: Bir bütünleştirme önerisi. Göç Dergisi, 3(1), 65 - 81.

Sanders, M. G., \& Harvey, A. (2002). Beyond the school walls: A case study of principal leadership for school-community collaboration. Teachers College Record, 104, 1345-1368.

Sarıtaş, E., Şahin, Ü. ve Çatalbaş, G. (2016). İlkokullarda yabancı uyruklu öğrencilerle karşılaşılan sorunlar. Pamukkale Üniversitesi Sosyal Bilimler Enstitüsü Dergisi, 25(1), 208-229.

Schwallie-Giddis, P., Anstrom, K., Sánchez, P., Sardi, V. A., \& Granato, L. (2004). Counseling the linguistically and culturally diverse student: Meeting school counselors' professional development needs. Professional School Counseling, 8, 15-23.

Sink, C. (2016). Incorporating a multi-tiered system of supports into school counselor preparation. Retrieved from http://tpcjournal.nbcc.org/wp-content/uploads/2016/09/Pages203-219-Sink.pdf

Solak, E. \& Çelik, S. (2018). Investigation of linguistic challenges faced by refugee students in Turkey. The Journal of International Social Research, 11(57), 425-433.

Stone, C. B., \& Clark, M. A. (2001). School counselors and principals: Partners in support of academic achievement. NASSP Bulletin, 85(624), 46-53. 
Taştekin, E., Bozkurt-Yükçü, Ş., İzoğlu, A., Güngör, İ., Işık Uslu, E. A. ve Demircioğlu, H. (2016). Okul öncesi öğretmenlerinin çok kültürlü eğitime yönelik tutumlarının ve algılarının incelenmesi. Hacettepe Üniversitesi Eğitim Bilimleri Enstitüsü Eğitim Araştırmaları Dergisi (HÜNER), 2(1), 1-20.

Türk PDR Derneği (2019). 21. Uluslararası Psikolojik Danışma ve Rehberlik Kongresi: Okul Psikolojik Danışmanlığı 2025 Vizyonu, Unvan ve Reformlar. Kongre Kitabı (Ed. E. HAMARTA). Kemer, Antalya.

U.S. Department of Education $(2019,2020)$. National Center for Education Statistics, Common Core of Data (CCD), "Local Education Agency Universe Survey," 2017-18. See Digest of Education Statistics 2019, table 204.20, 204.27 and 214.40.

Uluslararası Mülteci Hakları Derneği (UMHD). (2017). Suriye'de ihlaller ve Halep raporu. İstanbul: İNSAMER İnsani ve Sosyal Araștırmalar Merkezi.

Yildiz, N. G. (2020). A Qualitative Analysis: School Counselors' Role in Building Partnerships with Linguistically Diverse Families. Presented at 6th International Conference on Lifelong Education and Leadership for All-ICLEL 2020 July 16-18, 2020, Sakarya University Congress \& Culture Center Turkey

Ziomek-Daigle, J., Goodman-Scott, E., Cavin, J., \& Donohue, P. (2016). Integrating a multi-tiered system of supports with comprehensive school counseling program. http://tpcjournal.nbcc.org/integratinga-multi-tiered-system-of-supports-with-comprehensive-school-counseling-programs/

Wampold, B. E., \& Imel, Z. E. (2015). Counseling and psychotherapy. The great psychotherapy debate: The evidence for what makes psychotherapy work (2nd ed.). Routledge/Taylor \& Francis Group. 